\title{
Three Rival Views of Tradition (Arendt, Oakeshott and MacIntyre)
}

\author{
James Alexander \\ Dept. of Political Science, Bilkent University \\ jalexand@bilkent.edu.tr
}

\begin{abstract}
If we define tradition too hastily we leave to one side the question of what the relevance of tradition is for us. Here the concept of tradition is opened up by considering the different views of it taken by Hannah Arendt, Michael Oakeshott and Alasdair MacIntyre. We see that each has put tradition into a fully developed picture of what our predicament is in modernity; and that each has differed in their assessment of what our relation to tradition is or should be. Arendt sees tradition as something which no longer conditions action, Oakeshott sees tradition as something which conditions all action, and MacIntyre sees tradition as something which should condition right action. In each case, the view of tradition is clearly one element in an attempt to see how the most important constituent elements of human existence - variously called the human condition, human conduct, or human virtue - should be understood in a modernity which is ours because it has put the traditional concept of tradition into question.
\end{abstract}

\section{Keywords}

Tradition, Action, Practice, Arendt, Oakeshott, MacIntyre

This essay uses the writings of three twentieth-century philosophers who have written in English - Hannah Arendt, Michael Oakeshott and Alasdair MacIntyre - to show that the modern understanding of tradition cannot be limited to one definition. There are, at least, two concepts of tradition, and three rival views of what our relation to tradition must be. 
The standard modern definition of tradition, as it has emerged in the writings of sociologists, historians and philosophers in the last half century or so, is an abstract one. It is that tradition is simply anything that is transferred through time from generation to generation, is handed down in such a way that it is transformed (as well as transferred) by those who transfer it, and is handed down in such a way that not only the tradition itself, but those who transfer it, and any transformations made to it, are all legitimated by being traditional. Or, as Shils puts it, it is "anything handed down from past to present". It includes, he suggests, "material objects, beliefs about all sorts of things, images of persons and events, practices and institutions ... buildings, monuments, landscapes, sculptures, paintings, books, tools, machines... all that a society of a given time possesses and which already existed when it present possessions came upon it". ${ }^{1}$

The standard modern definition is good as far as it goes. But we can put it in question if we observe that it differs from the older (or traditional) meaning of tradition. The original term traditio, in Latin, which derived from the verb meaning 'to hand over', tradere, meant simply something which is handed over. Prickett, who has written about the history of the concept of tradition, writes that "there has actually been remarkably little change in the meaning of the word 'tradition' itself from the time when Tertullian and the Church Fathers took the Latin traditio, in its legal meaning of 'handing over' or 'delivery', and wrote by analogy of the Traditio evangelica - or Catholica." It is true, as he says, that from this time tradition has always been the word for "the historical conveyance of received notions", 3 but what we have to recognize is that this tradition was for most of its history a singular one. In Catholic Christianity there was one human tradition which handed over one divine truth. But in Protestant Christianity the tradition (associated with the church) was, for the first time, separated from the truth (associated with the Bible): a separation of kerygma and traditio which broke the original unity; and which led to the recognition, at least by the end of the seventeenth century, that religions existed in the plural, and, later, that cultures and truths also existed in the plural. So, by the time Shils

\footnotetext{
1) Edward Shils, Tradition (Chicago: Chicago University Press, 1981), 12.

2) Stephen Prickett, Modernity and the Reinvention of Tradition: Backing into the Future (Cambridge: Cambridge University Press, 2009), 28.

3) Ibid., 70.
} 
attempted to define tradition, he was at the end of a long history of drift from a view of tradition which related it to truth to a view of tradition which related it to more or less anything.

The standard modern definition of tradition, then, ignores truth. It is an abstraction. It does not relate to one truth but any ritual, symbol or situation, or, indeed, any truth - anything which conditions an activity. Tradition, understood this way, is plural, it is alterable and it is even inventable. ${ }^{4}$ We can see why Popper commented sixty years ago that any "theory of tradition" would have to be a "sociological theory" and why it is sociologists like Weber and Shils who are associated most strongly with theories of tradition. ${ }^{5}$ The sociologist stands back from traditions, which are endless in number, and studies them. But this involves the sociologist in a fundamental contradiction. For if traditions are everywhere, and condition all activity, then the understanding of the sociologist, the set of rules by which he studies traditions, and even his definition of tradition, themselves emerge from a tradition, of which his method of study is only an abridgement, or an abstraction. Oakeshott argued this way in 1947, saying that "rationalism" comes out of "tradition" and is therefore secondary to it: Popper attempted

4) For plural see Shils above. For alterable see the famous observation that "the whole existing order must be, if ever so slightly, altered", in T.S. Eliot, "Tradition and the Individual Talent' from Selected Prose of T.S. Eliot ed. Frank Kermode (Faber, 1975), 37-49 at 38. For inventable see Eric Hobsbawm, 'Inventing Traditions', in The Invention of Tradition ed. Eric Hobsbawm \& Terence Ranger (Cambridge: Cambridge University Press, 1983), 1-14. Hobsbawm's thesis is hard to take seriously: for either all tradition is invented, in which case the thesis tells us nothing distinctive about modern traditions; or the thesis does tell us something about modern traditions, in which case he fails to distinguish modern "invented" tradition from older (uninvented) ones. See Prickett, 14-15. Shils thought the thesis "frivolous". See Edwards Shils, A Fragment of a Sociological Autobiography: The History of My Pursuit of a Few Ideas ed. Stephen Grosby (London: Transaction, 2006), 130.

5) Weber thought tradition was on the "borderline" of "meaningfully orientated action". His famous distinction of rational or legal, traditional and charismatic authority was ad hoc: although it enabled him to establish for sociologists the category of tradition by which authority rests "on an established belief in the sanctity of immemorial traditions and the legitimacy of the status of those exercising authority under them (traditional authority)". See Max Weber, Wirtschaft and Gesellschaft, Part I, trans. Talcott Parsons and A.M. Henderson, The Theory of Social and Economic Organisation (Oxford, 1947), 115-16, 130 \& 328. Shils thought Weber was too concerned with authority, and had failed to see that tradition was ubiquitous. But Shils himself was more interested in "taxonomy" than "analysis". See Prickett, Modernity, 14. 
to defend "rationalism" in 1948, by acknowledging that "rationalism" is a "tradition", but by asserting nonetheless the primacy of "rationalism" according to a distinction between two types of tradition: "uncritical" or "first-order" traditions on the one hand and "critical" or "second-order" traditions on the other. ${ }^{6}$ The problem here was that this used "science" or "critique" - as sociology still often does - as a way of sidestepping the fact that tradition concerns us.

So not only do we have two concepts of tradition, one which relates it to one truth and another which relates it to any truth or practice. For if we ask what our relation to tradition is then there are three possibilities. Tradition is either nowhere, somewhere or everywhere. If it is everywhere it necessarily calls rationality into question, since it is a general condition of all activity. If it is merely somewhere or nowhere, it does not necessarily call rationality into question, but then there is the question of whether it should be separated from rationality or reconciled with it. And each of the thinkers explored one of these possibilities. Arendt thought tradition was nowhere, Oakeshott thought it was everywhere, and MacIntyre thought it was somewhere - and in each case they thought this had consequences for us. Tradition concerns truth or truths, or the absence of them: and as such all three took an understanding of tradition to be vital for an understanding of what they all called our "predicament". ${ }^{7}$

This essay is written out of a sense that contrasting Arendt's, Oakeshott's and MacIntyre's thought about tradition will not only establish a set of possibilities for what can be thought about tradition in modernity, but will separately clarify, through differentiation, the exact nature of certain element in each one's thought. As far as I know, this is the first attempt to contrast their understandings of tradition. ${ }^{8}$ None of the three wrote

6) Karl Popper, "Towards a Rational Theory of Tradition" (1948), Conjectures and Refutations: The Growth of Scientific Knowledge 3rd ed. (London: Routledge and Kegan Paul, 1969), 120-35, at 122, 123 \& 127. For Popper's response to Oakeshott ("a really original thinker") see 121. Popper's argument's influenced Shils, whose view of tradition, ironically, is similar to Oakeshott's. See Shils, Fragment, 128-33.

7) For "predicament" see Hannah Arendt, Between Past and Future (London: Penguin, 2006), 6, Michael Oakeshott, "Introduction to Leviathan", in Rationalism in Politics and Other Essays (Indianopolis: Liberty Press, 1991), 227, and Alasdair MacIntyre, After Virtue: A Study in Moral Theory, 2nd ed. (London: Duckworth, 1985), 263.

8) For literature on Arendt, see Bhikhu Parekh, Hannah Arendt and the Search for a New Political Philosophy (Atlantic Highlands, New Jersey: Humanities Press, 1981) and Hanna 
narrowly on tradition: all wrote about tradition in the course of writing about something else. Here they are considered loosely in order of chronology. Arendt's The Human Condition was published in $195^{8}$ and her On Revolution in 1963 , Oakeshott's Rationalism in Politics was published in 1962 and his On Human Conduct in 1975, and MacIntyre's After Virtue was published in 1981 and his Three Rival Versions of Moral Enquiry in 1985. Each of them, in the course of these writings, articulates a real rather than nominal definition of tradition: they want to say what tradition is as a res and not as mere nomina. Each relates tradition to action - although in importantly different ways. And it should become evident that Arendt has the least favorable view of tradition, Oakeshott a more favorable, and MacIntyre the most favorable.

There is another reason why I consider them in this order. Stories are very important for all three: the means by which we venture into history, and place ourselves, and our endeavors, in time. And what they each say about stories is revealing about what they think of tradition. For Arendt a story comes out of action: the "end result" of "action and speech" will "always be a story." So she emphasizes the beginning of a story. For Oakeshott a story "does not open with the unconditional, "In the beginning..." but with a conditional "Once upon a time...", and it does not come to a definitive end, for "its end is the beginning of another story." Stories have "no over-all meaning," they are just "occurrences understood in terms of

Fenichel Pitkin, The Attack of the Blob: Hannah Arendt's Concept of the Social (Chicago: Chicago University Press, 1998). For Oakeshott, see Paul Franco, The Political Philosophy of Michael Oakeshott (New Haven: Yale, 1990), and Terry Nardin, The Philosophy of Michael Oakeshott (University Park, Penn.: Pennsylvania State University Press, 2001). For MacIntyre After MacIntyre: Critical Perspectives on the Work of Alasdair MacIntyre eds. John Horton and Susan Mendus (Notre Dame, Indiana: University of Notre Dame Press, 1994). MacIntyre's understanding of tradition has received much more separate attention than Arendt's or Oakeshott's. See, for instance, Emily Gill, "MacIntyre, Rationality and the Liberal tradition", Polity 24 (1992): 433-57, J.B. Schneewind, "MacIntyre and the Indispensability of Tradition", Philosophy and Phenomenological Research 51 (1991): 165-8, Jennifer Herdt, "Alasdair MacIntyre's 'Rationality of Traditions' and Tradition-Transcendental Standards of Justification", The Journal of Religion 78 (1998): 524-546, Thomas Hibbs, "MacIntyre, Aquinas and Politics", The Review of Politics 66 (2004): 357-83. But see footnotes 12 and 52 below.

9) Hannah Arendt, The Human Condition 2nd ed. (Chicago: Chicago University Press, 1998), $97 \& 184$. 
the meaning they acquire from their evidential contingent relationships."10 In other words, he emphasizes not the beginning or end of a story, but its middle. For MacIntyre a story is only intelligible if it has a definite end. For even though any story is, as Arendt and Oakeshott agree, mired in unpredictability, it always has, MacIntyre adds, "a certain teleological character". ${ }^{11}$ So he emphasizes the end of a story.

And what we will see is that, what is true of stories is true of tradition: Arendt is concerned with beginnings, Oakeshott with middles and MacIntyre with ends.

\section{II}

For anyone concerned with beginnings, tradition is a problem, because although tradition has a beginning, or an original "moment of truth", it involves the perpetuation of that moment to later times, in such a way that it can interfere with or prevent later beginnings. This is the likely cause of Arendt's extremely clear separation of tradition from the concepts which especially concerned her: freedom, politics, action.

Arendt not only separates tradition from action philosophically; she also sees them as separate historically. Her view of history is that it involves a rupture. She takes the view that what made tradition substantively traditional in older times was that it was singular, it was assumed, and it was constitutive of the order in which men and women lived. And this is, in the 'modern age', no longer the case. We exist within the modernity which has been established by the decisive severing of history into two parts. Before the age of revolution, or the reforms carried out in the shadow of revolution, there was tradition; afterwards, there was not. And, as a consequence of this view of history, her view of tradition is not the abstract one of the standard modern definition: on the contrary, tradition is historical, is singular, is determinate, is, or was, our tradition - and the problem for us is that it is gone, destroyed by revolution. It should become evident that for

10) Oakeshott, On Human Conduct (Oxford: Clarendon Press, 1975), 105. Oakeshott here distinguishes a (third person) "story" from a (first person) "myth", which is closer to what Arendt and MacIntyre suppose a story to be.

11) MacIntyre, After Virtue, 213. On unpredictability compare Arendt, Human Condition, 182, Oakeshott, On Human Conduct, 105. 
her this tradition is Roman in the fullest sense - the Traditio Catholica mentioned above.

This view is put most clearly in On Revolution, the essays collected as Between Past and Future and the early drafts of work which were posthumously published as The Promise of Politics. Arendt never attempts to define tradition, and this has perhaps encouraged some of her commentators to assume that the "tradition" is a philosophical one. ${ }^{12}$ Arendt always writes as if the "tradition" begins with Plato; but it is not a philosophical tradition but an anti-political one which soon transcends mere philosophy. According to Arendt, Plato responded to the execution of Socrates by withdrawing from the polis into the Academy, by declaring that politics was a means to a philosophical life (vita contemplativa) not an end in itself (vita activa), and by distinguishing truth (which was singular) from opinion(which was plural) ${ }^{13}$ This taken by itself was a "degradation of politics." ${ }^{4}$ But Plato also introduced into some of his political writings myths which supposed that some sort of authoritative good could be imposed on people by threatening them with rewards and punishments in an afterlife. This introduced an "element of violence" into politics. ${ }^{15}$ This is perhaps the origin of tradition, but "before the Romans such a thing as tradition was unknown". ${ }^{16}$

Tradition, for Arendt, was always one element of the "Roman trinity" of "religion, tradition, and authority". ${ }^{17}$ It was, then, not an abstract "tradition" such as a sociologist could discover in any or all societies; on the contrary, it was the highly determinate tradition which had three stages - Greek,

12) Most of the literature on Arendt deals with this philosophical "tradition" but overlooks the fact that it was part of a "Roman trinity". See, for perhaps reluctant exceptions, Seyla Benhabib, The Reluctant Modernism of Hannah Arendt (Thousand Oaks: Sage Publications, 1996), 91, Margaret Canovan, Hannah Arendt: A Reinterpretation of Her Political Thought (Cambridge: Cambridge University Press, 1992), 68-71, and Shiraz Dossa, The Public Realm and the Public Self: The Political Theory of Hannah Arendt (Waterloo, Ontario: Wilfrid Laurier University Press, 1989), 154.

13) See Arendt, "Introduction into Politics", in The Promise of Politics ed. Jerome Kohn (New York: Schocken, 2005), 130-35.

14) Arendt, "The Promise of Politics", in The Promise of Politics, 83.

15) Arendt, "What is Authority?" in Between Past and Future, 132-5. Compare Simone Weil, Intimations of Christianity Among the Ancient Greeks trans. Elisabeth Chase Giessbuhler (London: Routledge and Kegan Paul, 1957).

16) Arendt, Between Past and Future, 25.

17) For this phrase, see Hannah Arendt, On Revolution (London: Penguin, 1990), 117, Arendt, Between Past and Future, 124, and Arendt, "The Promise of Politics", 50. 
Roman, Christian. Plato separated philosophy and politics: but it was with the foundation of Rome, the "Eternal City", and the adoption of Greek categories by the Romans, that there was the uniting of authority, religion and tradition beneath one Emperor; and it was through the foundation of a Christian Church in Rome that the same authority, tradition and religion were bound together beneath one God. ${ }^{18}$

[Tradition] preserved the past by handing down from one generation to the next the testimony of the ancestors, who first had witnessed and created the sacred founding and then augmented it by their authority throughout the centuries. As long as this tradition was uninterrupted, authority was inviolate; and to act without authority and tradition, without accepted, time-honored, standards and models, without the help of the wisdom of the founding fathers, was inconceivable. ${ }^{19}$

Arendt's view of history was that the end of this religion, tradition, and authority meant that other elements of human possibility which had been forgotten by the tradition were liberated. The "tradition" had forgotten "the experience of action as starting a new enterprise in pre-polis Greece, the experience of foundation in Rome, and the Christian experience of acting and forgiving as linked". ${ }^{20}$ It was not until the American and French revolutions that there was suddenly "the notion that the course of history suddenly begins anew, that an entirely new story, a story never known or told before is about to unfold". ${ }^{21}$ She explains her view of modern history in terms of the "pathos of novelty" in On Revolution. ${ }^{22}$ But it is in The Human Condition that she offers a theoretical account of what she supposes should exist in a world without tradition. This is "action".

Arendt never fully characterizes action. It is "one of the most important categories of Arendt's political philosophy, yet the least clearly defined". ${ }^{23}$ Sometimes she suggests it is words and deeds, and sometimes that it is only words. For others it might be social, or cultural, or ethical: but for

18) For elements of this story see Arendt, "The Promise of Politics", 49, 50 \& 6o, and Between Past and Future, 17 \& 25 .

19) Arendt, "What is Authority?", in Between Past and Future, 124.

20) Arendt, "The Promise of Politics", 60.

21) Arendt, On Revolution, 28.

22) For this phrase see ibid., 34 .

23) Parekh, Hannah Arendt, 113. 
her it is political. "The central political activity", she declares, "is action."24 The most important thing about this "action" is that cannot involve violence, force or hierarchy, as it has to fulfill the conditions of equality and plurality. ${ }^{25}$ And it is not to much to say that in Arendt's conceptual vocabulary action is politics is freedom. "Men are free", she says, "as long as they act, neither before nor after; for to be free and to act are the same." 26

She writes of the

actual content of political life - of the joy and gratification that arise out of our being in company with our peers, out of acting together and appearing in public, and of inserting ourselves into the world by world and deed, thus acquiring and securing out personal identity and beginning something entirely new. ${ }^{27}$

It is a world in which

...men in their freedom can interact with one another without compulsion, force, and rule over one another, as equals among equals, commanding and obeying one another only in emergencies - that is, in times of war - but otherwise managing all their affairs by speaking and persuading one another. ${ }^{28}$

Although she does not say so explicitly, this action is always momentary, of the moment. It is not conditioned by time, but is an emerging of the timeless into time. The theme of "beginning something entirely new" is important here. Her favorite quotation is Augustine's line Initium ut esset homo creatus est ante quem nullus fuit ("That a beginning might be made, man was created before whom nobody was"). ${ }^{29}$ Action, she says, is a realm of "natality" because in "action" there is always the possibility of the "new beginning inherent in birth", or the "capacity of beginning something anew;" indeed, all "action" is a beginning. This is a metaphor: but she

\footnotetext{
24) Hannah Arendt quoted by Margaret Canovan, The Human Condition, ix.

25) See Arendt, Human Condition, 26 \& 215. Compare Arendt, "Introduction Into Politics", 95.

26) Hannah Arendt, “What is Freedom?', in Between Past and Future, 151.

27) Hannah Arendt, "Truth and Politics", in Between Past and Future, 258-9.

28) Arendt, "Introduction Into Politics", 117.

29) For her habit of quoting this line (from Augustine, City of God, 12.20), see Arendt, The Human Condition, 177, "What is Freedom?" in Between Past and Future, 166, "The Promise of Politics", 59, On Revolution, 211, and even her last work The Life of the Mind (New York: Harcourt, Brace and Co., 1978), 217.
} 
considers it might be the most apt one. "Natality, and not mortality, may be the central category of political, as distinguished from metaphysical, thought."30

It is the necessary condition of our being able to act freely, then, that we are not subject to tradition. The truth in Arendt is not a singular one which needs to be handed over as the truth of Christ is handed over by the Church: it is a plurality of truths, our truths, which we discover in interaction with each other. ${ }^{31}$ Arendt's ideal is thus nothing more than the opposite of what is associated with "tradition". If tradition is associated with unity, coercion and truth, then action is associated with plurality, equality and - something less singular and coercive than truth - speech. If she had ever used the word "tradition" in an abstract, universal sense, for any tradition, then she would doubtless have emphasized only the beginnings of these traditions.

The reason I say this is that the shadows cast by the ruins of tradition over modern history and philosophy are a great preoccupation in her writings. Action is such a continual momentariness that it is threatened by any tendency to establish order through time - in law, morality or custom. She knows that "action" is subject to "the threefold frustration" of "the unpredictability of outcomes, the irreversibility of the process, and the anonymity of its authors". ${ }^{32}$ In The Human Condition she sketches a few abstract means by which action could survive its introduction into history: "promise" so that action does not simply dissolve in the moment, but survives into the future, and "forgiveness" so that action will never become fixed in such a way as to prevent further action. ${ }^{33}$ But in On Revolution, where she writes historically, she is more mordant about the fate of the revolutionary attempt to separate action from tradition. It failed. The revolutionaries attempted to "find a new secular absolute to replace the old religious absolute". ${ }^{34}$ And - according to the usual paradox of tradition - they

\footnotetext{
30) Arendt, Human Condition, 9.

31) Arendt disliked singular "truth" because it contained an "element of coercion". But she wanted to avoid relativism. See Arendt, "Truth and Politics", in Between Past and Future, 235, and John S. Nelson, "Politics and Truth: Arendt's Problematic", American Journal of Political Science 22 (1978): 270-301.

32) Arendt, Human Condition, 220.

33) Ibid., 237.

34) Arendt, On Revolution, 39. Cf. 116, 184-5 \& 191. See also Arendt, "What is Authority?", in Between Past and Future, 134.
} 
soon shifted from revolting against tradition to forming a "revolutionary tradition". This tradition, she claims, was based on "opposites - the right and the left, reactionary and progressive, conservatism and liberalism" which were "two sides of the same event" but which after the revolution "parted company, solidified into ideologies, and began to oppose each other". ${ }^{35}$ The rise of party politics perpetuated the failure of revolution: for instead of "action" there was only "representation" - the French sociétés populaires, American 'republics' and Bolshevik soviets were all forgotten and that "the spirit of revolution - a new spirit and the spirit of beginning something new - failed to find its appropriate institution." ${ }^{36}$

Arendt's is a powerful view of tradition - "our tradition" - which attempts to theorize history in terms of "the actor or agent" and not in terms of "the spectator who watches a spectacle. ${ }^{37}$ She sees tradition as a determinate and unitary tradition, which is lost to us, because we no longer believe in its truth; but which has a legacy that causes endless difficulties in our apparently post-traditional society. Arendt did not use the term "post-traditional" but she could well have done. We could say that her writings are the clearest attempt in modernity to see what life in a post-traditional society could entail. If that is one way of putting it, the other is to say, as Parekh says, that Arendt "is unable to appreciate the importance of traditions in political life." 38

No one would ever have said that of Oakeshott.

III

For anyone concerned with middles, tradition is simply the condition of all action. When one is in the middle of something, one is not concerned only with situation, not origin or destination. Oakeshott, I have said, is concerned with middles. His theory is the same as Shils's: that, in a sense, everything we do is traditional. He, too, emphasizes practices rather than truth. But he, like Arendt, theorizes it in relation to action, although not at all as she does.

\footnotetext{
35) Arendt, On Revolution, 223.

36) Ibid., 280.

37) Ibid., $5^{2 .}$

38) Parekh, Hannah Arendt, 179.
} 
Oakeshott does not separate action and tradition as Arendt does; but, rather, understands action as something necessarily enveloped in tradition. Here I will mainly consider his late work On Human Conduct which, interestingly, does not use the word "tradition" but uses the word "practice" instead. However, Oakeshott's thought was laced with tradition: explicitly so, famously, in the essays collected as Rationalism in Politics - and, as we shall see, there is no reason to think he changed his mind about the importance of tradition. There is no doubt that Oakeshott wrote at a higher level of abstraction than Arendt and MacIntyre. He wrote about tradition at a philosophical level, whereas Arendt and MacIntyre did not. But it is important to note that Arendt and MacIntyre could not write philosophically, since they were concerned with actual, rather than abstract, traditions. And, as I have already suggested, one of the great ambiguities of tradition is that the more abstract the concept of tradition is taken to be the more it comes to lack what makes a tradition a tradition - which is its actuality.

In On Human Conduct Oakeshott begins, as Arendt does, with action. ${ }^{39}$ His characterization of action is similar to Arendt's and may even have been indebted to it. ${ }^{40}$ Oakeshott puts "actions and utterances" together as Arendt put "words and deeds" together. "A man may perform an action, he make undertake a course of action, and he may make utterances which are themselves actions or are auxiliaries to actions." 41 But Oakeshott is skeptical of attempts - whether psychological or sociological - to explain action. "A belief is what it means to the believer." 42 And so he characterizes action in the most abstract sense possible. It is a "human being responding to his contingent situation by doing or saying this rather than that in relation to an imagined and wished-for outcomes and in relation, also, to some understood conditions." 43 There are two elements here: anyone who acts has an understanding of his "wants" and an understanding of his "world." And Oakeshott attempts to sketch some of the consequences of this: action seeks satisfactions, and responses; it is, as Arendt suggested, unpredictable; it involves deliberation between alternative actions; and it involves

\footnotetext{
39) Oakeshott discusses action in Human Conduct, $31 \mathrm{ff}$.

40) See, for instance, the suggestion that the outcome of an action is "always a new situation calling for a new response". Oakeshott, Human Conduct, 45.

41) Ibid., 31.

42) Ibid., 23.

43) Ibid., 32.
} 
persuasion as its characteristic form of speech. ${ }^{44}$ But, most importantly, since action depends on understanding, and, indeed, is "an illustrative exhibition of this understanding", it is something which has to be "learned". 45

Actions are "ad hoc," "terminable," mere "transactions," but as they depend not only on an understanding of wants but also on an understanding of the world they presuppose more durable conditions which he calls, in On Human Conduct, "practices". ${ }^{46}$ A practice is "a set of considerations, manners, uses, observances, customs, standards, canons, maxims, principles, rules and offices specifying useful procedures or denoting obligation or duties which relate to human actions and utterances." ${ }^{n 7}$ In other words, practices are not actions, but the conditions of actions. They are "recognizable" when they "acquire a certain degree of definition and authority or acknowledged utility." They are the outcome of former actions: they can be neglected, suppressed or abolished, and that they can be affected now or in the future by the actions they qualify. ${ }^{48}$ All conduct - that is, action or utterance - takes place in terms of a "multiplicity of practices". And in his theory Oakeshott sketches a hierarchy of "a multiplicity of arts and practices presided over by a practice of moral conduct and perhaps a religious faith". ${ }^{49}$

In this way Oakeshott effectively demotes action from its Arendtian height. We are related, then, not through actions, but through practices, that is, through the conditions to which we subscribe when we act. We are not at the beginning: we are in the middle. These practices are substantial, and they culminate in morality ("the practice of all practices") and religion (also a "practice").50 Oakeshott, who writes philosophically, is not concerned with the absolute status of religion (or tradition or authority) but with the relative status of practices to human conduct. He does not assume that religion exists or does not exist, but treats it as something which may exist. So he discusses religion; and, later, he discusses authority - but always

\footnotetext{
44) Ibid., 40-46.

45) Ibid., 32.

46) Ibid., 57. He discusses practices from $54 \mathrm{ff}$.

47) Ibid., 55 .

48) Ibid., 56 .

49) Ibid., 86.

50) For morality see ibid., 6o-81 and for religion, 81-86.
} 
in the abstract (any authority, any religion). ${ }^{51}$ He does not use the word "tradition". But it is now a matter of common knowledge that in On Human Conduct Oakeshott uses the word "practice" where he formerly used "tradition."52

Oakeshott does not use the word "tradition" because it is "inadequate to express what [he] want[s] to express." ${ }^{33} \mathrm{He}$ avoids it not because it is inadequate in itself, but because he wants to avoid being misunderstood as a Burkean in either sense: in the sense of simply defending a particular ancien regime, as Burke did, or in the sense of defending any ancien regime, as a Burkean might. ${ }^{54}$ The advantage of the word "practice" is that it enables him to avoid the risk of appearing to defend any substantive tradition. In his earlier writings he uses "tradition" in an abstracted sense, to stand for the abstract features possessed by any tradition, which he considers are as open to change as MacIntyre thinks they are; but in On Human Conduct he uses the word "practice" to make misunderstanding impossible. Traditions, or "practices", are contingent, ambiguous and miscellaneous: they supply the conditions in which crisis is experienced and the answers out of which salvation can be sought.

Since Oakeshott nowhere adopts what could be called an absolute, or dogmatic, conception of tradition (in terms of "truth"), his earlier conception of a tradition, an abstract and relative conception, is indistinguishable

51) Ibid., 149-154.

52) In Oakeshott's first book, Experience and Its Modes, "practice" is simply all practical experience, all actions with purposes in mind. But this is different from what he later means by a set of understood conventions: he calls this first "tradition", and later (after 1958) "practice". This has been well recognized by Franco, The Political Philosophy of Michael Oakeshott, 132-3 \& 170-71, Robert Devigne, Recasting Conservatism: Oakeshott, Strauss, and the Response to Postmodernism (London: Yale University Press, 1994), 17, Nardin, The Philosophy of Michael Oakeshott, 76, and Luke O'Sullivan, Oakeshott on History (Exeter: Imprint Academic, 2003), 112 \& 176-77. There is an entire chapter on this in Kenneth B. MacIntyre, The Limits of Political Philosophy: Oakeshott's Philosophy of Civil Association (Exeter: Imprint Academic, 2004), 41-76.

53) Michael Oakeshott, "On Misunderstanding Human Conduct”, Political Theory 4 (1976): 364. The only time he mentions "tradition" in On Human Conduct is in the form "traditio" when he writes about religion. See 81 .

54) For a view of Oakeshott as Burkean see Pitkin, "The Roots of Conservatism", 249, 254 \& 256. For a counter see Franco, The Political Philosophy of Michael Oakeshott, 7, 108 \& 136-40. Oakeshott was always concerned to counter such misunderstandings. See Oakeshott, "On Misunderstanding Human Conduct", 353-67. 
not only from what he later meant by a practice, but is also indistinguishable from what sociologists like Shils have offered as a characterization of a tradition in the abstract. ${ }^{55} \mathrm{An}$ action is what it is: what is important is the context for action, which is a practice, or a tradition. It is in this way - and this is where there is a contrast with Arendt - that Oakeshott relates action and tradition. And it is, incidentally, as decisive for his view of politics as Arendt's view of action was for hers.

Oakeshott suggests that politics is not prior to an established order but subsequent to it, and that this established order is best understood in terms of tradition. Since politics is "the activity of attending to the general arrangements of a set of people whom chance or choice have brought together," it follows that the arrangements and the activity of attending to them are an

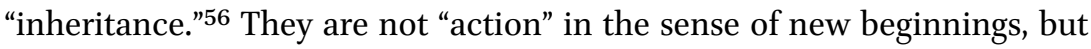
"action" as conditioned by "tradition". So the proper study of politics is not an "ideological" one in which a "system of ideas" is "abstracted" from a tradition but is a "traditional" one - "an exploration of a tradition, an initiation into an inheritance, an observation and imitation of ... our elders." ${ }^{57}$

Oakeshott's restoration of a relation between "action" and "tradition" suggests a very different conception of politics to that of Arendt. Whereas Arendt excludes all hierarchy, and therefore all rule and government, from her conception of politics, Oakeshott considers politics a response to such rule. Politics is the "engagement of considering the desirability of the conditions of conduct prescribed in respublica, of imagining and wanting them to be in some respect different from what they, and of recommending and promoting a change from what is to imagined and allegedly more desirable condition. ${ }^{58}$ This, again, is a conception of politics in terms of tradition. There is no ideal politics to be achieved in a revolution which breaks through all religion, tradition and authority: on the contrary, politics is not only an activity conditioned by "practices" but is itself the consideration of

55) Cf. "Actions are not handed down; only their models, rule and legitimations are." Edward Shils, "Tradition", Comparative Studies in Society and History 13, no. 3 (1971): 127. See also Shils, Tradition, 31, and, for that matter, J.G.A. Pocock, "Time, Institutions and Action: An Essay on Traditions and their Understanding", Politics, Language and Time: Essays on Political Theory and History (New York: Athenaeum, 1971), 233-72.

56) Oakeshott, "Political Education", in Rationalism and Politics and Other Essays (Indianapolis: Liberty, 1991), 43-69, at 44-5.

57) Ibid., $51 \& 62$.

58) Oakeshott, Human Conduct, 161. 
the "practices" associated with rules and ruling - the consideration of whether traditions should be changed or not. ${ }^{59}$

Oakeshott's definition of tradition is not a sociological definition, although, like that of Shils, it can be used of any tradition. It is abstract, and, like the sociological definition, it is capacious: it excludes nothing. The problem with this understanding of tradition is that it overlooks the tension which Arendt and MacIntyre in very different ways perceive as having being the tension of all tensions for over two hundred years, which is the tension between the older doctrine of the "image of God" (religion, tradition and authority) and the modern doctrine of the "works of man" (revolution, politics and action). ${ }^{60}$ Many commentators have alleged that one of the major weaknesses of Oakeshott's thought is that it appears to ignore the fact that there does seem to be a distinction between the traditions of a traditional society and the traditions of a post-revolutionary society. Modern politics is constituted by a lack of authoritative tradition in many parts of the world which have been affected by revolution. ${ }^{61}$ Rationalism may have been a mistake, but it is an old mistake, and one which - as Arendt saw - has its own traditions: so it is too late to consider that identifying that mistake can explain how we should act now in a sometimes traditionless world. Oakeshott, in saying that tradition is prior to rationality, makes it impossible to know what rationality can achieve where there is no obvious tradition, or where there are rival traditions.

Oakeshott does not think this is a problem because he defines tradition in such abstract terms that tradition is whatever we have. But MacIntyre, like almost everyone who defines tradition more narrowly, and less abstractly, does think there is a problem.

59) Cf. the claim, that politics is dependent on "law and custom and tradition". Michael Oakeshott, "The Claims of Politics" in Religion, Politics and the Moral Life ed. Timothy Fuller (New Haven: Yale University Press, 1993), 93.

60) See Edward Craig, The Mind of God and the Works of Man (Oxford: Clarendon, 1987).

61) "The traditions of most countries no longer provide very illuminating intimations of how to cope with daily political reality." John Dunn, Modern Revolutions: An Introduction to the Analysis of a Political Phenomenon 1972, 2nd ed. (Cambridge University Press, 1989), 261. "The advice to look to tradition and enhance coherence by pursuing intimations is simply meaningless where no worthwhile tradition exists... Oakeshott has simply nothing to say to people without a tradition to conserve." Hanna Fenichel Pitkin, "The Roots of Conservatism: Michael Oakeshott and the Denial of Politics", in The New Conservatives: A Critique from the Left ed. Lewis A. Coser and Irving Howe (New Times Book Co., 1974), 262. 
IV

For anyone concerned with ends, it is extremely important to assess whether a tradition is the right way to achieve certain ends or not. And this means that while Arendt could dismiss or relativize the problem of "truth" and Oakeshott could avoid it, MacIntyre is led to consider tradition in relation not only to practices (in the plural) but also to truth (in the singular).

When MacIntyre is writing about tradition in the abstract he sounds remarkably like Oakeshott. He declares as robustly as Oakeshott does in After Virtue that any conception of action which ignores "intentions, beliefs and settings" is "utterly doomed to failure." 62 He says that "action" is "a potentially misleading abstraction": no more and no less than a "moment" in history, which has no meaning outside a practice, a narrative, a tradition which brings it into history. ${ }^{63}$ All action has two conditions: one is that it occurs with a frame of unpredictability - this is no different from anything said by Oakeshott, or even Arendt; the second is that "action" always has "a certain teleological character" because it is framed by some conception of the good - this is wholly different. Neither Arendt nor Oakeshott are concerned with ends. ${ }^{64}$ But for MacIntyre every moment involves an "image of some future and an image of the future which always presents itself in the form of a telos." 65

MacIntyre agrees with Oakeshott that "action" has to be seen within "tradition". But while Oakeshott avoids the negative associations of the word "tradition", and used the word "practice" instead, MacIntyre uses both. And what we see is that he has a less abstract concept of a practice than Oakeshott because he defines it in terms of its end. He uses the word "practice in a specially defined way which does not completely agree with current ordinary usage". By a practice he means

\footnotetext{
62) MacIntyre, After Virtue, 208.

63) Ibid., 214.

64) This is why for MacIntyre, as a good Aristotelian, politics is inseparable from ethics, while for Arendt and Oakeshott politics is always politics. See MacIntyre, "Politics, Philosophy and the Common Good" (1997) in The MacIntyre Reader ed. Kelvin Knight (Note Dame, Indiana: University of Notre Dame Press, 1998), 235-52.

65) MacIntyre, After Virtue, 215.
} 
any coherent and complex form of socially established co-operative activity through which goods internal to that form of activity are realized in the course of trying to achieve those standards of excellence which are appropriate to, and partially definitive of, that form of activity, with the result that human powers to achieve excellence, and human conceptions of the ends and goods involved, are systematically extended. ${ }^{66}$

So a practice is neither any sort of activity nor any set of conditions within which activity occurs; but a particular sort of activity which involves the assumption of the "authority" of "standards of excellence" and a willing "obedience to rules" which enable the activity to be judged in relation to such standards. ${ }^{67}$ It is, in short, related to a good. So while Oakeshott calls a practice a set of standards, MacIntyre calls a practice an activity carried out according to a set of recognized or established or conscious standards. In both cases, a practice is, in the end, indistinguishable from tradition. MacIntyre observes, as Oakeshott does, that all practices have a history. "To enter into a practice is to enter into a relationship not only with its contemporary practitioners, but also with those who have preceded us in the practice": it is, therefore, a "tradition". ${ }^{68}$ The difference is that Oakeshott's understanding of tradition is capacious, and includes every practice, even an unreasonable one (on the Hegelian assumption that reason is cunning), while MacIntyre's understanding of tradition is one excludes unreasonable theories or practices. This is because if something is a good, or an end, it requires justification.

It is central to the conception of such a tradition that the past is never something merely to be discarded, but rather that the present is intelligible only as a commentary upon and response to the past in which the past, if necessary and if possible, is corrected and transcended, yet corrected and transcended in a way that leaves the present open to being in turn corrected and transcended by some yet more adequate future point of view. ${ }^{69}$

\footnotetext{
66) Ibid., 187.

67) Ibid., 190.

68) Ibid., 194.

69) Ibid., 146.
} 
MacIntyre is ostentatiously hostile to the view of "tradition" taken by Burke and other "conservative political theorists."70 Burke, according to MacIntyre, opposed reason to tradition (much as Arendt does); whereas MacIntyre insists that "all reasoning takes place within the context of some traditional mode of thought" (much as Oakeshott does). So "when a tradition becomes Burkean, it is always dying or dead." ${ }^{71}$ His view of tradition is that it is "an historically extended, socially embodied argument, and an argumentprecisely in partabout the goods which constitute that tradition." ${ }^{2}$ Since it is an "argument" and only defensible as such, it cannot depend on unargued beliefs.

The view of tradition MacIntyre sketches in After Virtue and Whose Justice? Which Rationality? is very similar to that of Oakeshott. Except in these works MacIntyre asks the question Oakeshott did not ask: namely, how a tradition can continue to establish itself in a situation where, as Arendt might put it, the Roman trinity of religion, tradition and authority has been destroyed and there are now only traditions in the plural, each of which has its own view "of what rational superiority consists in". ${ }^{73}$ MacIntyre's answer is something he calls the "rationality of traditions". Since there is no rationality without tradition and no tradition without rationality, "we cannot adequately identify either our own commitments or those of others in the argumentative conflicts of the present except by situating them within those histories which made them what they have now become." ${ }^{74}$ He sketches

three stages in the initial development of a tradition: a first in which the relevant beliefs, texts and authorities gave not yet been put in question; a second in which inadequacies of various types have been identified, but not yet remedied; and a third in which response to those inadequacies has resulted in a set of reformulations, revaluations, and new formulations and evaluations, designed to remedy inadequacies and overcome limitations. ${ }^{75}$

\footnotetext{
70) Ibid., 221.

71) Ibid., 222. MacIntyre returns to the "bastardized" conception of tradition inherited from Burke by modern conservatives in MacIntyre, Whose Justice? Which Rationality? (London: Duckworth, 1988), 8, 165 \& 353 .

72) MacIntyre, After Virtue, 222.

73) MacIntyre, Whose Justice?, 348.

74) Ibid., 13.

75) Ibid., 355 .
} 
This is still fairly abstract: there is nothing in it that Oakeshott, or indeed, Arendt, would object to. But in Three Rival Versions of Moral Enquiry he puts forward explicitly a view which is only implicit in the other books. This is the view that there is, in principle, one unitary tradition which is capable of conceptualizing itself rightly as a tradition in a substantive sense and opposing itself to other rival ways of understanding existence. And it is at this point that MacIntyre entirely parts company with Oakeshott.

For when, in Three Rival Versions, MacIntyre explicitly opposes "tradition" to "encyclopedia" and "genealogy", he no longer uses "tradition" as a word for any tradition, but (perhaps what it always was) a word for one tradition. Each of these three "versions" is associated with a "seminal latenineteenth century text: the Ninth Edition of the Encyclopaedia Britannica, Nietzsche's Zur Genealogie der Moral and the encyclical letter of Pope Leo XIII Aeterni Patris." 76 Encyclopaedia is a way of seeing the world objectively, in terms of the possibility of rational agreement - which would give us a unified science in which one truth can be known under different categories, a "single neutral nonpartisan history", and a morality of ethical enlightenment. ${ }^{77}$ Genealogy is a way of seeing the world subjectively, in terms of radical disagreement - which would give us no stable science at all (since there is "no such thing as truth-as-such, but only truth-from-one-orother-point-of-view"), a history of "social and psychological formations in which the will to power is distorted into and concealed by the will to truth", and a morality of rancor and resentment. ${ }^{78}$

Genealogist and encyclopaedist agree in framing what they take to be both exclusive and exhaustive alternatives: either reason is thus impersonal, universal, and disinterested or it is the unwitting representative of particular interests, masking their drive to power by its false pretensions to neutrality and disinterestedness. What this alternative conceals from view is a third possibility. ${ }^{79}$

\footnotetext{
76) Ibid., 2.

77) See, especially, ibid., $16-19,151$ \& 42.

78) MacIntyre, Three Rival Versions of Moral Enquiry (London: Duckworth, 1985), 33, 35-36, $39 \& 41$.

79) Ibid., 59.
} 
Tradition is here a way of seeing the world absolutely, in terms of a canon. It involves the view that rational enquiry is only possible within a community in which certain values are already recognized and shared - it involves "the concept of having to be a certain sort of person, morally or theologically, in order to read a book aright." 80 This view, unlike genealogy, supposes reason to have content, and, unlike encyclopedia, does not suppose that truth is accessible to anyone. It requires a "teacher". This contradicts encyclopaedism, where to be rational is to think for oneself, and genealogy, where to follow an authority is to be subject to power and perversion. ${ }^{81}$ And it requires a "tradition" which can be taught. For Mac-Intyre, this is, interestingly, exactly the same tradition Arendt supposes was destroyed by revolution - or, as Popper would have it, rationalism.

MacIntyre is still rationalist enough to think that tradition needs to be argued for. But his tradition requires authority, exactly because there is no rationality available to all humanity without authority. ${ }^{82}$ And authority requires religion: for while the encyclopaedist attempts to "displace the Bible as a canonical book', in order to establish a new canon, and the genealogist "discredit[s] the whole notion of a canon", the traditionalist seeks to "preserve and justify the canonical status of the Bible as distinct from, yet hegemonic over, all secular enquiry". ${ }^{83}$ This is the restoration of Arendt's "Roman trinity" of religion, tradition and authority - with (as is crucial for MacIntyre) rationality added to make it a quaternity.

All we can notice about this position is that it even though MacIntyre appears to make "tradition" less abstract, he does not commit himself entirely to the view - what he imagines is Burke's view - that tradition is prior to rationality; so he is in the odd situation of appearing to insist both that one "tradition" is prior to rationality and that rationality is prior to tradition. This is the point at which MacIntyre's thought is fundamentally ambivalent. MacIntyre could say, what he does not say, that there are two layers of tradition: firstly, the abstract and plural traditions - which Oakeshott describes - where every action is traditional in the sense that it is conditioned by inherited practices, and secondly the determinate and singular tradition - which Arendt describes - which is the true type of a

\footnotetext{
80) Ibid., 133 .

81) Ibid., 64.

82) Ibid., 91 \& 99-100.

83) Ibid., 5 .
} 
tradition of which all others are fragments or imitations. It seems at times as if he wants to say this, but his own writing oscillates between the claim that there is one tradition which is intrinsically authoritative because it descends from revelation and the concession that no tradition is likely to be able to achieve dominance according to the secular, liberal or rational values he himself espouses. ${ }^{84}$

V

This essay is a contribution to the understanding of tradition in modernity. Tradition is far from being a simple, or closed, subject. Here we have at least three rival views of tradition. As indicated in the writings of Arendt, Oakeshott and MacIntyre, tradition may be nowhere, it may be everywhere, or it may be somewhere. There is no definitive view of where tradition is to be found. We may suppose that the concept of tradition, for the time being, has to oscillate between two extreme conceptions: the first, that tradition originates in eternal truth - whether the logos of Plato or the Gospel of John - or it originates in any truth which emerges in time - Nietzsche's "my truth". Everything else follows from these. If tradition originates in an eternal truth, then it must always appeal to this truth in something like contemporaneity: through repeated ritual, something like Christian communion, confession or conversion, all of which are moments which replicate the eternal truth represented in the first instance at the moment of the crucifixion. If tradition originates in this sort of truth, then it is one. If it is right, it is right; if it is wrong, a mistake, then tradition is simply misleading, a trick by which various orders have been perpetuated in the service of ends extraneous to those professed: ends of power, influence, exploitation etc. If this is so, then it is our duty to repudiate tradition and the truth which lies behind it. But as everyone has observed, from Popper onwards, the paradox of tradition is that even an opposition to tradition becomes a tradition. And this makes possible the expanded, or abstract, or Oakeshottian, view of tradition, which is that more or less anything which can be thought or done in a sense comes out of continuity, and is conditioned by some sort of tradition (and, some would say, by some sort of authority, some sort of

84) Lewis Hinchman, "Virtue or Autonomy: Alasdair MacIntyre's Critique of Liberal Individualism", Polity 21 (1989): 635-54. 
religion). In this sense, tradition cannot be wrong: indeed, here, there is no distinction between right and wrong, which is why this conception of tradition appeals to the sociologists, who want a term which can capture everything humans do. But, as long as humans do have a sense of right and wrong - which appears to be part of what it is to be human at all - then the other conception of tradition will always cast a shadow at the very least, and perhaps cast light, on what we say and do.

What we can say about the writers considered in this essay is that each has understood this problem in a different way. This is because each has different concerns. We could say - since the titles of their books suggest as much - that Arendt's concern is with the human condition, Oakeshott with human conduct, and MacIntyre's with human virtue. Arendt's concern is with the conditions necessary for men and women to achieve the shared but relative good of acting together, Oakeshott's is with the conditions necessary for men and women to achieve their own individual goods, and MacIntyre's is with the conditions necessary for men and women to achieve an absolute good. All three are concerned with the good in some form: but Arendt's is a good of action, Oakeshott's a good of constitution, and MacIntyre's a good of intention. There is no question that, of the three, Oakeshott writes at the highest, or more abstract, level about tradition; but it is part of my claim that this is as much a disadvantage as an advantage: because when a discussion of tradition becomes abstract - more philosophical and less historical (as well as less practical) - it becomes less relevant to our actual situation, where only particular or determinate traditions can be relevant. Oakeshott no doubt sees this: the structures of his thought indicate that he does; but he nonetheless insists that the philosopher is only concerned with abstraction. Arendt and MacIntyre, with different consequences, do not. They see history and philosophy as infinitely tangled. Oakeshott would say that Arendt and MacIntyre were practically rather than theoretically concerned with tradition; but Arendt and MacIntyre would say that Oakeshott's distinction between theory and practice depends on an arbitrary abstraction from the fact that any theorist himself writes out of and any actor acts within a determinate set of traditions.

Arendt understands tradition in terms of beginnings - beginnings which interrupt traditions (and start new ones); that Oakeshott understands traditions in terms of middles - middles which specify neither the origin of traditions nor their destination, but legitimate the existence of traditions in 
general; and that MacIntyre understands tradition in terms of ends - ends which justify one tradition above all others. As we have already observed, all three of these writers see life, or modern life, as a "predicament." Arendt dislikes tradition and thinks it obscures an adequate response to this predicament, Oakeshott is indifferent to any particular tradition but thinks it a necessary element in any response to this predicament, and MacIntyre seeks the one tradition which he thinks is the only adequate response to this predicament.

This comparison makes the weakness of each evident. Arendt is suffused with the pathos of beginnings, and suffers from imaginative failure when it comes to seeing beyond them: so that when she writes about history she forces her ideals into history like a set of reproaches, as if men and women cannot escape the tradition they have nonetheless left behind. Oakeshott, the most systematic, and least prone to exaggeration, is guilty however of ironical understatement of difficulty, in supposing that tradition is simply whatever we have. We could say he is suffused with the pathos of middles. And MacIntyre, determined to see the furthest, is only prevented from committing himself to absolute truth out of a commitment to codes of reason which support the liberalism he remains opposed to. He, alone, emphasizes the importance of a telos. So he is suffused with the pathos of ends. But between the three of them, and with requisite seriousness, we have perhaps a complete account of what it is possible for us now to think.

The purpose of this essay has been comparative exposition, or, rather, exposition of three separate accounts of tradition - considered by this author to be three of the most interesting of the last century or so. We can say, in conclusion, that Arendt embodies the pure hope of modernity, in thinking we can shed tradition and make a new beginning, that Oakeshott, less hopeful, observes that we are in a "middle" which is always conditioned by tradition, and that MacIntyre reminds us that our traditions can take us nowhere without truth. Arendt captures the dawn, Oakeshott the day, and MacIntyre the dusk. 